\title{
Local metropolitan government responses to homelessness in South Africa
}

\author{
Jacques du Toit ${ }^{1}$
}

This article examines metropolitan government responses to homelessness in South Africa, including the context of responses, preparedness to respond, factors influencing responses, shelter locations, and homeless persons' views. Whereas the literature emphasises the need for spatial or physical interventions, this research, using multiple case studies, found that three out of four metropolitan municipalities viewed homelessness primarily as a social dependency issue and responded with social interventions. Yet homeless persons indicated that the most important thing the municipality could do for them was to provide employment and well-located affordable housing. The study concludes that municipalities might respond more effectively with spatial or physical interventions such as equitable urban planning and design and sensitive land use management, and by providing affordable housing close to places of employment.

Keywords: local government; metropolitan municipality; homelessness; affordable housing; low-cost housing; urban planning

\section{Introduction}

A local television channel recently screened a documentary on what is becoming an increasingly familiar sight in South Africa's inner cities and suburbs: people living on the streets. It showed provocative footage of pockets of homeless people living in unhygienic conditions against the walls of security complexes in the affluent northern suburbs of Johannesburg. Asked why they were living there they typically responded that they had come to look for work, but that they had no money to pay for a place to stay, or to go back to the places they came from, or to commute. The residents' answer to this was typically that municipal bylaws were being grossly violated and that the municipality should restore law and order.

The State of our Cities Report from the South African Cities Network (SACN) shows that South Africa's six metropolitan municipalities of Cape Town, Ekurhuleni (East Rand), eThekwini (Durban), Johannesburg, Nelson Mandela (Port Elizabeth) and Tshwane (Pretoria) have 'strong' economies compared to the national economy in terms of Gross Value Added (GVA) output, and in some cases 'stronger' (SACN, 2006:3:8-9). Yet these municipalities also have large numbers of low skilled unemployed immigrants, and historically their economies have had difficulty absorbing such immigrants (SACN, 2004:51). They also have a large percentage of the national population living below the minimum living level (MLL):

\footnotetext{
1 Lecturer, Department of Town and Regional Planning, University of Pretoria. Correspondence:
} jacques.dutoit@up.ac.za 
eThekwini has over a million (4\% of the national total), Johannesburg over 865000 (3.7\%), Cape Town over 718000 (3\%) and Tshwane over 500000 (2\%) (SACN, 2006:2-17). Many of these low skilled unemployed immigrants living below the MLL would constitute homeless people such as those seen in the television documentary. Nowhere in South Africa are concentrations of homeless people more visible than on the sidewalks of metropolitan municipalities.

Since homelessness in the large cities is likely to increase in the foreseeable future, and since it affects the well-being of not only the homeless but also the public in general, it is important to ask how these municipalities are responding to homelessness, how prepared they are, what factors influence their responses, and where they locate shelters. This paper reports applied research that formed part of a larger Human Sciences Research Council (HSRC) study of homelessness triggered by the removal of the growing number of homeless people who slept in front of the HSRC building in central Pretoria.

It examines local metropolitan government responses, looking in particular at the municipal departments primarily responsible for dealing with homelessness. Adopting a critical social science perspective, it describes these responses with the aim of identifying possible gaps or detrimental practices in these responses and recommending improvements. It looks also at the views of homeless persons surveyed by the HSRC, to get an idea of the effectiveness and appropriateness of these responses. The paper should of course be read in conjunction with papers in this special issue that explore other aspects of homelessness.

\section{Defining 'homelessness' in a metropolitan context}

Caplow et al. (1968:494) define homelessness as 'a condition of detachment from society characterised by the absence or attenuation of the affiliative bonds that link settled persons to a network of interconnected social structures'. This definition, although cited often in the literature, is limited to the social-psychological problems of detached homeless persons and does not consider their actual housing circumstances. Rahimian et al. (1992) and Glasser (1994:3) furthermore point out that although this definition might be suitable for developed countries, it is less suitable for developing countries where there are large numbers of informal settlement dwellers. The South African Homeless Peoples' Federation, for example, regards informal settlement dwellers as 'homeless'. Nevertheless, even though it is not proper housing, informal housing could still be regarded as a home - a place of retreat that is usually located within a recognisable settlement pattern with social structures that are often stronger than those of formal settlements. Aliber (2002:12) also notes that detached homeless persons appear to be different from informal settlement dwellers, but acknowledges that 'there is no clear line separating the two'. What then does 'homelessness' mean in a South African metropolitan context?

A brief study by Aliber et al. (2004) of the homeless who slept in front of the HSRC building revealed that, apart from some detached homeless persons, most of them had homes and social ties in townships and informal settlements. These people were searching for work in central Pretoria but could not afford to commute daily from townships or informal settlements outside Pretoria. As a result, they felt they had little choice but to sleep in the inner city. These homeless people can be referred to as 'temporary overnight sleepers'. Chances are that this is a typically South African phenomenon and that there are similar groups of homeless people across all six South Africa's metropolitan municipalities, since the peripheral location of 
townships and informal settlements is characteristic of South African cities. In fact, the HSRC's homelessness survey (described in detail by Cross and Seager, this issue) revealed that $48.4 \%$ of homeless persons in Johannesburg and Tshwane said they had a home, but that it was too far and too costly to commute from their homes on a daily basis, whereas only $32.5 \%$ had no permanent home and $19.1 \%$ were temporarily stranded.

Three groups of homeless persons can, for the purpose of this article, be identified in a South African metropolitan context: detached homeless persons, temporary overnight sleepers (including evictees and 'weekday' homeless persons), and informal settlement dwellers. The first two of these three groups can be referred to collectively as 'street homeless persons', since they typically live on the streets of metropolitan municipalities. In this article, the terms 'homeless' and 'homelessness' are used to refer to street homeless persons only.

\section{The literature on homelessness}

Studies on local government responses to homelessness can be divided into two groups: nonempirical (i.e. theoretical and normative) and empirical (i.e. research). Most non-empirical studies originate from the US and take a critical social science perspective, also described in the literature as a 'critical humanist' or 'neo-Marxist' perspective. These studies were in reaction to welfare reforms that included housing subsidy and social service reductions during the Reagan administration (Wolch, 1997, 1998; Wolch \& Sommer, 1997), which Da Costa Nunez and Caruso (2003:46) argue significantly increased homelessness during the 1980s and 1990s. Many of these studies argue that the way municipalities plan, design and control urban space has a significant impact on homelessness, for better or worse (Wright, 1997; Lofland, 1998; Mitchell, 2001; Snow \& Mulcahy, 2001; Amster, 2003; Murray, 2004). For example, municipalities might plan, design and control inner city public spaces to exclude or displace 'undesirable groups' such as homeless persons to attract investment or stall the flight of businesses to the suburbs. Yet most of the homeless live in the inner city public spaces, or 'zone of dependence' as Dear and Wolch (1987) and Lee and Prince-Spratlen (2004:21) call it, because they depend on having access to busy public spaces to beg, sell favours, forage for food, and so on. How municipalities plan, design and control urban space therefore affects the survival of homeless people in the most fundamental way. Robins (2002) and Murray (2004:29) describe the control of urban space to achieve social ends as 'spatial governance', and Oakley (2002) and Mitchell (2001:67) explain how even businesses and communities exercise 'spatial governance' by using zoning restrictions to exclude facilities for the homeless, arguing that they will attract 'undesirables' and cause property values to decline and crime to increase, and the quality of life to deteriorate. Non-empirical studies of homelessness therefore highlight the importance of considering the relationship between homelessness and urban space when looking at local metropolitan government responses.

Empirical studies of homelessness focus mostly on the causes and socioeconomic conditions of homelessness (Roth, 1985; Rossi, 1987; Jahiel, 1992; Burt, 1992; Snow \& Anderson, 1993, as cited by Berman \& West, 1997:304; Glasser, 1994:8). The structural causes of homelessness were studied by Elliott and Krivo (1991), Honig and Filer (1993) and Lee et al. (2003) and found to include lack of affordable housing, lack of employment and adequate health care, and an increase in the number of single-headed households. Studies in a metropolitan context focus on the spatial distribution of homelessness and the effect of land use policies on the provision of services for the homeless (Dear \& Wolch, 1987; Wolch \& Dear, 1993). Besides these studies of developed countries, there are also numerous studies of 
homelessness in developing countries, although these focus more on urbanisation and housing shortages (Cole, 1987; Drakakis-Smith, 1987; Gugler, 1988; Dogan \& Kasarda, 1988, cited by Glasser, 1994:8; Furnell, 1996).

According to Hoch (2000), the way local governments view homelessness largely determines their responses. They tend to see it as an issue of either social dependency or lack of affordable housing or moral failure. Hoch argues that the social dependency view currently dominates local government policy in the US, with the focus being on making homeless people less dependent instead of providing affordable housing so they can leave the shelters. Hoch's criticism of this view is that once the homeless are given some form of independence they often fall back into homelessness as they cannot afford private housing in the rental market. Hoch further argues that they should rather be seen as people with 'shelter uncertainty' who struggle to find housing. Elliott and Krivo (1991), Daly (1996:169), Berman and West (1997:304), America magazine (2003), Amster (2003), Da Costa Nunez and Caruso (2003) and Lee et al. (2003) argue that local governments should view homelessness as a problem of lack of affordable housing. Poulsen (2000) reviewed the Transitional Housing Programme in central Johannesburg and points out that those who exited one of the five facilities as part of the programme often re-entered them when they were not able to find affordable housing.

Daly (1996) studied the role of local governments in Britain, Canada and the US and found similarities as well as differences between them. Local governments in all three countries were described as having experienced a wave of neoconservatism since the 1980s, which coincided with an increase in homelessness and decline in affordable rental housing. British local governments were required to house homeless people on a 'priority need' basis, although implementation differed across regions. Although the federal government in the US enacted homelessness legislation in 1987, a laissez faire approach continued, while public involvement was limited to the provision of emergency shelters. Canada had no specific homelessness legislation, although the provision of social housing to accommodate a range of income groups was seen as relatively successful (Daly, 1996:189).

Studies focusing specifically on the responses of metropolitan municipalities are limited. Berman and West (1997) conducted a survey in the US on the preparedness of metropolitan municipalities to respond to homelessness. US metropolitan municipalities tend to use a comprehensive range of programmes and strategies, while the federal government acts as funder and prompter. Although more than half of all municipalities surveyed used most of the interventions listed in the survey questionnaire, it was also reported that programmes in many municipalities were implemented under conditions of funding shortages, fragmentation, public apathy and compassion fatigue. The most important factor influencing municipal responses was economic circumstances (Berman \& West, 1997:303-4, 314-5). Since no study had yet been done locally on the responses of metropolitan municipalities, the survey instrument of the Berman \& West study served as a basis for this study, and this also enabled comparisons between US and South African findings.

\section{Research design and methods}

This research was based on comparative case studies of four of the six metropolitan municipalities in South Africa, Cape Town, eThekwini, Johannesburg and Tshwane, carried out during 2004 and 2005. Each study used a mixed methods approach that included the 
collection, analysis and interpretation of primary and secondary qualitative data and primary quantitative data.

Qualitative primary data on the context of municipal responses were obtained through unstructured face-to-face and focus group interviews with officials coordinating these responses in each of the four metropolitan municipalities, and qualitative secondary data were obtained from various news articles, municipal websites and municipal documents such as policies, strategies, programmes and research reports (see summary in Table 1). Qualitative primary data on the preparedness of municipalities to respond and factors influencing these responses were obtained through a standardised questionnaire completed by the official responsible for homelessness in each of the four metropolitan municipalities. The officials had to tick check boxes denoting a range of possible interventions and make choices on a 4-point Likert scale to denote the importance of a range of factors influencing responses (see Tables 2 and 3). The mapping of shelter locations around the inner cities of each of the four metropolitan municipalities was based on address lists of shelters owned by the municipalities. Finally, quantitative primary data on homeless people's views were obtained from the HSRC survey in the central parts of Johannesburg and Tshwane. Cape Town and eThekwini were not included in this survey. The survey data were analysed using descriptive and inferential statistics and are reported in Tables 4 and 5.

\section{Discussion of responses}

\subsection{Context of responses}

Table 1 synthesises, summarises and compares the context of municipal responses to homelessness across the four metropolitan municipalities. Much of the information in this table was obtained from municipal documents. 
Table 1: Context of responses

\begin{tabular}{|c|c|c|c|c|}
\hline & Johannesburg & eThekwini & Cape Town & Tshwane \\
\hline $\begin{array}{l}\text { Department } \\
\text { responsible for } \\
\text { homelessness } \\
\end{array}$ & $\begin{array}{l}\text { Social Development } \\
\text { (Social services) / } \\
\text { Housing }\end{array}$ & Housing & $\begin{array}{l}\text { Social Development } \\
\text { (Programme for Street } \\
\text { People) }\end{array}$ & $\begin{array}{l}\text { Social Development / } \\
\text { Housing }\end{array}$ \\
\hline $\begin{array}{l}\text { View of reason for } \\
\text { homelessness }\end{array}$ & Social dependency & $\begin{array}{l}\text { Lack of low-cost } \\
\text { housing / Social } \\
\text { dependency }\end{array}$ & $\begin{array}{l}\text { Social dependency / } \\
\text { Lack of low-cost } \\
\text { housing (Indirect } \\
\text { reference to moral } \\
\text { failure) }\end{array}$ & $\begin{array}{l}\text { Social dependency / } \\
\text { Lack of low-cost } \\
\text { housing (Indirect } \\
\text { reference to moral } \\
\text { failure) }\end{array}$ \\
\hline $\begin{array}{l}\text { Estimated number of } \\
\text { homeless persons } \\
\text { (including adults \& } \\
\text { children) }\end{array}$ & $\begin{array}{l}\text { Between } 4000 \text { and } \\
6000 \text { (According to } \\
\text { some interviewees the } \\
\text { figure has dropped to } \\
\text { about } 1200 \text { ) }\end{array}$ & $\begin{array}{l}\text { No information } \\
\text { available }\end{array}$ & $\begin{array}{l}4133 \text { ( } 3351 \text { adults \& } \\
782 \text { children) }\end{array}$ & $\begin{array}{l}\text { More than } 2000 \text { (or } \\
\text { about } 1400 \text { in the } \\
\text { inner city) }\end{array}$ \\
\hline $\begin{array}{l}\text { Estimated number of } \\
\text { shelters (including } \\
\text { public and privately } \\
\text { owned) }\end{array}$ & $\begin{array}{l}\text { Between } 12 \text { and } 15 \\
\text { (most are privately } \\
\text { owned) }\end{array}$ & $\begin{array}{l}\text { About } 5 \text { (in and } \\
\text { around the inner city) }\end{array}$ & $\begin{array}{l}32 \text { (15 adult and } 17 \\
\text { child shelters - all } \\
\text { privately owned) }\end{array}$ & $\begin{array}{l}35 \text { (most are privately } \\
\text { owned) }\end{array}$ \\
\hline $\begin{array}{l}\text { Current approaches to } \\
\text { homelessness }\end{array}$ & $\begin{array}{l}\text { Coordinating civil } \\
\text { society responses / } \\
\text { Transitional housing }\end{array}$ & $\begin{array}{l}\text { Street children } \\
\text { programmes / } \\
\text { Relocation / } \\
\text { Enforcing minimum } \\
\text { standard requirements } \\
\text { in shelters }\end{array}$ & $\begin{array}{l}\text { Coordinating civil } \\
\text { society responses / } \\
\text { Awareness campaigns } \\
\text { / Promoting social } \\
\text { justice / Community } \\
\text { participation / } \\
\text { Strengthening existing } \\
\text { public and private } \\
\text { sector services } \\
\end{array}$ & $\begin{array}{l}\text { Coordinating civil } \\
\text { society responses / } \\
\text { Skills development / } \\
\text { Social and economic } \\
\text { upliftment }\end{array}$ \\
\hline $\begin{array}{l}\text { Current metro police } \\
\text { responses to } \\
\text { homelessness }\end{array}$ & $\begin{array}{l}\text { Responding to } \\
\text { complaints / } \\
\text { Enforcing bylaws / } \\
\text { Displacing }\end{array}$ & $\begin{array}{l}\text { Responding to } \\
\text { complaints / } \\
\text { Enforcing bylaws / } \\
\text { Displacing }\end{array}$ & $\begin{array}{l}\text { Responding to } \\
\text { complaints / } \\
\text { Monitoring }\end{array}$ & $\begin{array}{l}\text { Responding to } \\
\text { complaints / } \\
\text { Monitoring / } \\
\text { Displacing / } \\
\end{array}$ \\
\hline
\end{tabular}

It is the social development departments that are mainly responsible for homelessness, the housing departments less so. This helps to explain why three of the four municipalities viewed homelessness as a social dependency issue, emphasising the need for developmental programmes to 'empower' homeless people to find employment and housing and to escape their 'welfare mentality'. Only Johannesburg was responding by providing housing through the Johannesburg Property Company's 'Better Building Programme', in which derelict buildings were identified and refurbished for social or transitional housing. Nevertheless, interviewees from three municipalities said their homeless populations consisted more of semi-skilled or informally employed people who simply lacked housing, and less of detached persons who were homeless 'by choice' and for whom 'there was little hope', and interviewees from Tshwane's housing department, who were managing the HSRC shelter initiative at the time of the research, argued on the basis of their firsthand experience of the homeless that homelessness in Tshwane was not so much an issue of social dependency as of a lack of affordable housing. The fact that there was disagreement within municipalities, with some officials seeing, and treating, homelessness primarily as a social dependency issue, whereas experience on the ground indicates that it is perhaps more an issue of lack of affordable housing, suggests that some municipalities should reconsider their view of homelessness on a policy level.

The estimated numbers of homeless persons across the four municipalities varied between 2000 and 6000 at the time of the research, although data sources were sketchy with regard to numbers. Despite the availability of estimated numbers of public and privately owned shelters across the four municipalities, it was difficult to assess whether these shelters would be 
sufficient to accommodate the estimated numbers of homeless persons. Any assessment was further complicated by the transient nature of homeless populations, as well as unconfirmed initiatives at the time of the research such as the conversion of large derelict buildings into shelters in central eThekwini and Johannesburg.

Interviewees from three of the four municipalities said their current approach to homelessness was first and foremost to coordinate civil society responses. However, interviewees viewed public-private partnerships (PPPs) as having only limited success because their policy, legislative, institutional and implementation frameworks were fragmented. They said there was a need for stronger PPPs, although some interviewees from Tshwane, after recalling their experience with certain faith-based organisations, were sceptical about PPPs because of their 'hidden agendas'.

Metro police responses appear to be similar across all four municipalities - responding to complaints, enforcing bylaws and displacing homeless people. In Cape Town, a special 'Vagrancy Unit' was established to respond to public complaints. In Tshwane, street children in central Pretoria would be repeatedly rounded up and dropped off in townships, although the HSRC homelessness initiative seemed to have raised awareness with the metro police of the need to respond more cautiously. Nevertheless, shelter operators in the east of Tshwane reported that metro police responses had included acts of harassment, unnecessary displacement and even stealing from homeless people. Shelter operators also reported that the municipality had cut down trees and burned vegetation in open spaces in the eastern suburbs to make the homeless people more visible to the metro police and the area less habitable. Although it is important that metro police do respond to public complaints and enforce municipal bylaws, it is also important that there are appropriate measures in place whenever homeless persons are displaced, such as taking them to shelters, and reuniting them with associates or relatives if possible. Simply displacing them and making open spaces less habitable is plainly not a long-term solution. Moreover, many homeless people in the eastern suburbs of Tshwane were also reported to be construction workers. Construction companies should be required to help with transport or provide temporary accommodation on large construction sites.

A cursory overview of recent news articles following the case studies suggests that some metropolitan municipalities have adopted what seem to be anti-homelessness policies in preparation for the 2010 Soccer World Cup. Cape Town has adopted a 'prevention of nuisances bylaw', which is said by some to criminalise the homeless. Municipal officials, however, said the new bylaw will award homeless people 'more rights' by making begging legal, provided it is 'not done aggressively'. The implementation of the new bylaw is also said to be coupled with sensitivity training for metro police officials to ensure that they treat homeless persons with dignity when enforcing the bylaw (Powell, June 2006). The Supreme Court of Appeal recently allowed Johannesburg to evict about 300 squatters from inner city buildings classified as unsafe. Other 2010 host cities are expected to follow Johannesburg's example (IRIN News, 2007).

\subsection{Preparedness to respond}

The preparedness of metropolitan municipalities to respond was determined by looking at the use the four municipalities made of a wide range of possible interventions. Table 2 tabulates and quantifies officials' 'yes/no' responses to a standardised questionnaire asking about their preparedness for four types of interventions. 
Table 2: Preparedness to respond

\begin{tabular}{|c|c|c|c|c|}
\hline & Johannesburg & eThekwini & Cape Town & Tshwane \\
\hline $\begin{array}{l}\text { The municipality } \\
\text { has... }\end{array}$ & \multicolumn{4}{|c|}{ Preparedness in terms of planning/knowledge/research } \\
\hline $\begin{array}{l}\text { an employee } \\
\text { specialised in } \\
\text { homelessness }\end{array}$ & Yes & Yes & Yes & No \\
\hline $\begin{array}{l}\text { adopted a } \\
\text { homelessness policy }\end{array}$ & Yes & Yes & Yes & No \\
\hline $\begin{array}{l}\text { implemented a } \\
\text { homelessness strategy }\end{array}$ & Yes & Yes & Yes & Yes \\
\hline $\begin{array}{l}\text { conducted research on } \\
\text { homelessness }\end{array}$ & No & No & Yes & Yes \\
\hline $\begin{array}{l}\text { an annual report on } \\
\text { homelessness }\end{array}$ & Yes & No & Yes & No \\
\hline $\begin{array}{l}\text { Number of } \\
\text { interventions used }\end{array}$ & 4 out of a possible 5 & 3 out of a possible 5 & 5 out of 5 & 2 out of a possible 5 \\
\hline $\begin{array}{l}\text { Total no. of } \\
\text { interventions used in } \\
\text { category }\end{array}$ & \multicolumn{4}{|c|}{14 out of a possible 20 (70\%) } \\
\hline $\begin{array}{l}\text { The municipality } \\
\text { has... }\end{array}$ & \multicolumn{4}{|c|}{ Preparedness in terms of resources/funding } \\
\hline $\begin{array}{l}\text { participated in } \\
\text { intergovernmental } \\
\text { working groups } \\
\end{array}$ & Yes & No & Yes & Yes \\
\hline $\begin{array}{l}\text { applied for provincial } \\
\text { or national funding }\end{array}$ & Yes & Yes & Yes & No \\
\hline $\begin{array}{l}\text { a consolidated budget } \\
\text { for homelessness }\end{array}$ & No response & No & Yes & No \\
\hline $\begin{array}{l}\text { municipal tax for } \\
\text { homelessness } \\
\text { programmes } \\
\end{array}$ & Yes & No & No & No \\
\hline $\begin{array}{l}\text { Number of } \\
\text { interventions used }\end{array}$ & 3 out of a possible 4 & 1 out of a possible 4 & 3 out of a possible 4 & 1 out of a possible 4 \\
\hline $\begin{array}{l}\text { Total no. of } \\
\text { interventions used in } \\
\text { category }\end{array}$ & \multicolumn{4}{|c|}{8 out of a possible $16(50 \%)$} \\
\hline $\begin{array}{l}\text { The municipality } \\
\text { has... }\end{array}$ & \multicolumn{4}{|c|}{ Preparedness in terms of implementation/community coordination/PPPs } \\
\hline $\begin{array}{l}\text { cooperated with } \\
\text { voluntary } \\
\text { organisations to } \\
\text { provide services }\end{array}$ & Yes & No & Yes & Yes \\
\hline $\begin{array}{l}\text { partnerships for } \\
\text { housing programmes }\end{array}$ & Yes & No & No & No \\
\hline $\begin{array}{l}\text { encouraged private } \\
\text { sector involvement }\end{array}$ & No response & Yes (but limited) & Yes & Yes \\
\hline $\begin{array}{l}\text { contracted private } \\
\text { sector programmes }\end{array}$ & No response & No & Yes & No \\
\hline $\begin{array}{l}\text { community-based } \\
\text { planning }\end{array}$ & No & No response & Yes & Yes \\
\hline $\begin{array}{l}\text { coordinated } \\
\text { metropolitan and non- } \\
\text { metropolitan services }\end{array}$ & No & Yes (but limited) & Yes & Yes \\
\hline $\begin{array}{l}\text { partnerships for job } \\
\text { training }\end{array}$ & Yes & No & Yes & No (but forthcoming) \\
\hline $\begin{array}{l}\text { partnerships for health } \\
\text { programmes }\end{array}$ & Yes & No & Yes & Yes \\
\hline $\begin{array}{l}\text { provided public } \\
\text { awareness campaigns }\end{array}$ & Yes & No & Yes & No (but forthcoming) \\
\hline $\begin{array}{l}\text { Number of } \\
\text { interventions used }\end{array}$ & 5 out of a possible 9 & 2 out of a possible 9 & 8 out of a possible 9 & 5 out of a possible 9 \\
\hline
\end{tabular}




\begin{tabular}{|c|c|c|c|c|}
\hline & Johannesburg & eThekwini & Cape Town & Tshwane \\
\hline $\begin{array}{l}\text { Total no. of } \\
\text { interventions used in } \\
\text { category }\end{array}$ & \multicolumn{4}{|c|}{20 out of a possible 36 (56\%) } \\
\hline
\end{tabular}

Table 2: Preparedness to respond (continued)

\begin{tabular}{|c|c|c|c|c|}
\hline & Johannesburg & eThekwini & Cape Town & Tshwane \\
\hline $\begin{array}{l}\text { The municipality } \\
\text { has... }\end{array}$ & \multicolumn{4}{|c|}{ Preparedness in terms of programmes } \\
\hline $\begin{array}{l}\text { prevention } \\
\text { programmes }\end{array}$ & Yes & No response & Yes & No \\
\hline emergency assistance & Yes & Yes & No & No response \\
\hline primary health care & Yes & Yes & No & No \\
\hline $\begin{array}{l}\text { primary job and } \\
\text { housing programmes }\end{array}$ & No & Yes & No & No \\
\hline $\begin{array}{l}\text { long-term care } \\
\text { programmes }\end{array}$ & No & No & No & No \\
\hline $\begin{array}{l}\text { Number of } \\
\text { interventions used }\end{array}$ & 3 out of a possible 5 & 3 out of a possible 5 & 1 out of a possible 5 & None \\
\hline $\begin{array}{l}\text { Total no. of } \\
\text { interventions used in } \\
\text { category }\end{array}$ & \multicolumn{4}{|c|}{7 out of a possible 20 (35\%) } \\
\hline $\begin{array}{l}\text { Total no. of } \\
\text { interventions used } \\
\text { by municipality }\end{array}$ & $\begin{array}{c}15 \text { out of a total of } 23 \\
(65 \%)\end{array}$ & $\begin{array}{c}9 \text { out of a total of } 23 \\
(39 \%)\end{array}$ & $\begin{array}{c}17 \text { out of a total of } 23 \\
(74 \%)\end{array}$ & $\begin{array}{c}8 \text { out of a total of } 23 \\
(35 \%)\end{array}$ \\
\hline $\begin{array}{l}\text { Total no. of } \\
\text { interventions used } \\
\text { across all } \\
\text { municipalities }\end{array}$ & \multicolumn{4}{|c|}{49 out of a total of $92(53 \%)$} \\
\hline
\end{tabular}

Source: The four groups of interventions, planning/knowledge/research, resources/funding, implementation/community coordination/PPPs, and programmes were adapted from Berman \& West (1997).

At the time of the research, the four metropolitan municipalities were using $53 \%$ of all possible interventions to respond to homelessness. They were well prepared in terms of planning/knowledge/research interventions, as they were using $70 \%$ of the possible interventions in this category (with Cape Town using all of them), but poorly prepared in terms of programmes, as they were using only $35 \%$ of the possible interventions in this category (with Tshwane using none of them, although they were at a planning stage). Cape Town appeared to be the most prepared overall, as it was using $74 \%$ of all the possible interventions, followed by Johannesburg (65\%), eThekwini (39\%) and Tshwane (35\%). Only two of the four metropolitan municipalities, therefore, were using a majority of possible interventions - a situation similar to that of the US, where $54 \%$ of metropolitan municipalities were using a majority of possible interventions (Berman \& West 1997:309).

Although the municipalities were well prepared at a policy level, their lack of preparedness on the levels of resources and implementation would have made it difficult for them to put their policies into action in the form of tangible programmes on the ground. Moreover, despite the emphasis that interviewees in three of the four municipalities placed on lack of affordable housing as an important cause of homelessness, only Johannesburg said it had 'partnerships for housing programmes', and only eThekwini said it had 'primary job and housing programmes'.

\subsection{Factors influencing responses}

The factors influencing the responses of each of the four metropolitan municipalities were determined by looking at officials' ratings of the importance of a range of factors. Table 3 
tabulates their ratings on a 4-point Likert scale ranging from 'unimportant' to 'somewhat important', 'important' and 'very important'.

None of the factors were rated unimportant, which suggests that officials thought that responses to homelessness were influenced by almost any factor. Thus, it was a question of the relative importance of the factors. Table 3 shows that 'national government' was considered the most important category of factors, as three of the municipalities rated it 'very important'. The policy, legislative and financial support municipalities may or may not receive from national and provincial governments are therefore more important than any other factor when it comes to responding to homelessness. In the US, however, 'economic circumstances' rather than 'higher governments' was shown to be the most important factor (Berman \& West, 1997:313). 'Policy and administration' was considered the least important category of factors - however, this was because two factors in this category, 'changes in mental health policy' and 'overload of criminal justice system', were rated only 'somewhat important' by Tshwane. The other two factors in this category, 'lack of rehabilitative services' and 'cuts in national assistance programmes', were actually considered 'important' to 'very important’ by officials from all four municipalities.

Considering factors individually, 'provincial government' and 'increased use of emergency shelters' appeared to be the most important factors influencing responses, as these two factors were rated 'very important' by all three metropolitan municipalities that responded to these items. 'Changes in mental health policy', 'increased domestic violence' and 'increased begging' appeared to be the least important factors, as Tshwane considered the first two only 'somewhat important', while the third was considered only 'important' by all four metropolitan municipalities. It is surprising that 'domestic violence' was one of the factors rated least important considering the high levels of domestic and gender violence in South Africa. 
Table 3: Rating of factors influencing responses

\begin{tabular}{|c|c|c|c|c|}
\hline & Johannesburg & eThekwini & Cape Town & Tshwane \\
\hline \multicolumn{5}{|c|}{ Higher governments } \\
\hline National & Important & $\begin{array}{l}\text { Don’t know / Not } \\
\text { applicable }\end{array}$ & No response & Very important \\
\hline Provincial & Very important & $\begin{array}{c}\text { Don't know / Not } \\
\text { applicable }\end{array}$ & Very important & Very important \\
\hline \multicolumn{5}{|c|}{ Local government } \\
\hline $\begin{array}{l}\text { Director of } \\
\text { community } \\
\text { development / } \\
\text { housing }\end{array}$ & Very important & Somewhat important & No response & Very important \\
\hline Mayor & Very important & Somewhat important & Very important & Very important \\
\hline City manager & $\begin{array}{l}\text { Don’t know / Not } \\
\text { applicable }\end{array}$ & Somewhat important & Very important & Very important \\
\hline \multicolumn{5}{|c|}{ Private initiatives } \\
\hline $\begin{array}{l}\text { Religious } \\
\text { organisations }\end{array}$ & Important & Important & Important & Very important \\
\hline $\begin{array}{l}\text { Community } \\
\text { organisations }\end{array}$ & Very important & Somewhat important & Important & Very important \\
\hline Private citizens & Very important & $\begin{array}{c}\text { Don't know / Not } \\
\text { applicable }\end{array}$ & Important & Very important \\
\hline Local business groups & Very important & $\begin{array}{c}\text { Don't know / Not } \\
\text { applicable }\end{array}$ & Important & Very important \\
\hline \multicolumn{5}{|c|}{ Economic circumstances } \\
\hline $\begin{array}{l}\text { Poverty and low } \\
\text { income }\end{array}$ & Very important & Very important & Somewhat important & Very important \\
\hline $\begin{array}{l}\text { Lack of affordable } \\
\text { housing }\end{array}$ & Very important & Very important & Somewhat important & Important \\
\hline $\begin{array}{l}\text { Low level of } \\
\text { minimum wage }\end{array}$ & Important & Very important & Somewhat important & Very important \\
\hline $\begin{array}{l}\text { Rise in } \\
\text { unemployment }\end{array}$ & Very important & Very important & Somewhat important & Very important \\
\hline \multicolumn{5}{|c|}{ Policy and administration } \\
\hline $\begin{array}{l}\text { Lack of rehabilitative } \\
\text { services }\end{array}$ & Important & Important & Very important & Very important \\
\hline $\begin{array}{l}\text { Changes in mental } \\
\text { health policy }\end{array}$ & Important & $\begin{array}{c}\text { Don't know / Not } \\
\text { applicable }\end{array}$ & Very important & Somewhat important \\
\hline $\begin{array}{l}\text { Cuts in national } \\
\text { assistance } \\
\text { programmes }\end{array}$ & Very important & Important & Very important & Important \\
\hline $\begin{array}{l}\text { Overload of criminal } \\
\text { justice system }\end{array}$ & Very important & Important & Very important & Somewhat important \\
\hline \multicolumn{5}{|c|}{ Community circumstances } \\
\hline $\begin{array}{l}\text { Increased use of } \\
\text { emergency shelters }\end{array}$ & Very important & $\begin{array}{l}\text { Don’t know / Not } \\
\text { applicable }\end{array}$ & Very important & Very important \\
\hline $\begin{array}{l}\text { Overload of } \\
\text { community } \\
\text { organisations }\end{array}$ & Very important & $\begin{array}{l}\text { Don't know / Not } \\
\text { applicable }\end{array}$ & Important & Very important \\
\hline $\begin{array}{l}\text { Increased domestic } \\
\text { violence }\end{array}$ & Very important & Important & Important & Somewhat important \\
\hline $\begin{array}{l}\text { Increased number of } \\
\text { personal crises }\end{array}$ & Very important & Important & Important & Very important \\
\hline Increased begging & Important & Important & Important & Important \\
\hline
\end{tabular}

Source: The six groups of factors, higher governments, local government, private initiatives, economic circumstances, policy and administration, and community circumstances were adapted from Berman \& West (1997).

\subsection{Shelter locations}

Because the literature highlighted the importance of the relationship between homelessness and urban space when looking at local metropolitan government responses, the locations of the shelters were also taken into account. Figures 1 to 4 show the location of municipal owned 
shelters in and around the inner cities of each of the four metropolitan municipalities. There was a clear pattern of shelter locations just outside the inner city core in areas that could mostly be deemed zones of transition. Shelters are probably located here because these zones typically have lower land values than the inner city core (because of conflicting land uses, urban decline, and so on), but also because these zones are relatively close to social and economic opportunities in the inner city core.

Nevertheless, because of the stigma attached to zones of transition, homeless people, already stigmatised themselves, often suffer further stigmatisation by living in these zones - a process known as 'socio-spatial stigmatisation' (Takahashi, 1997) or 'ghettoization' (Wolch, 1980). As long as there are appropriate social and economic opportunities for homeless persons, it is probably not a very important concern whether shelters are located in stigmatised spaces or not. However, the mapping of the shelters in this study raises awareness that the location of shelters in South African metropolitan municipalities appears to have a particular socio-spatial logic behind it. 
Map 1: Shelter locations around Cape Town inner city

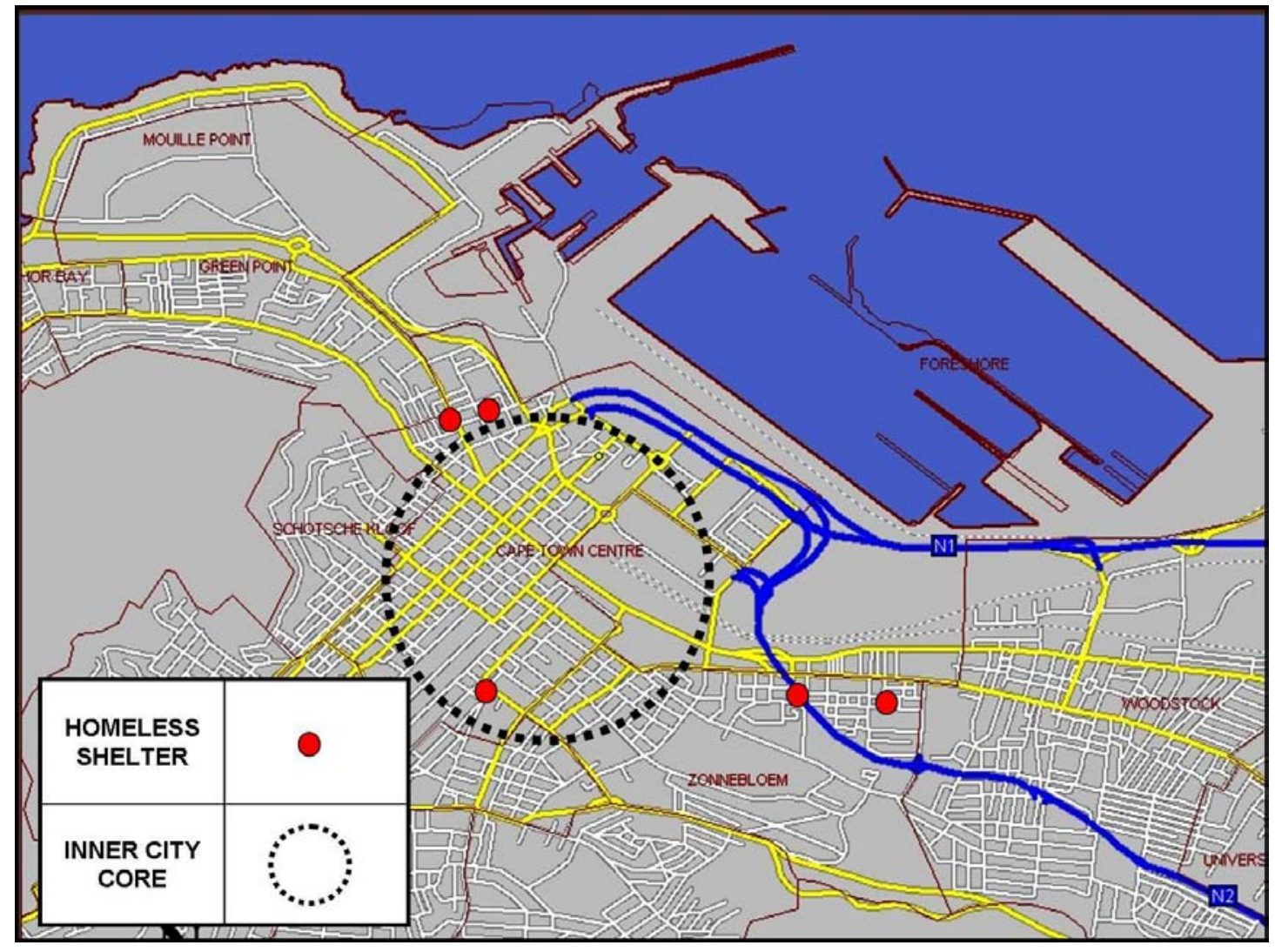


Map 2: Shelter locations around Durban inner city

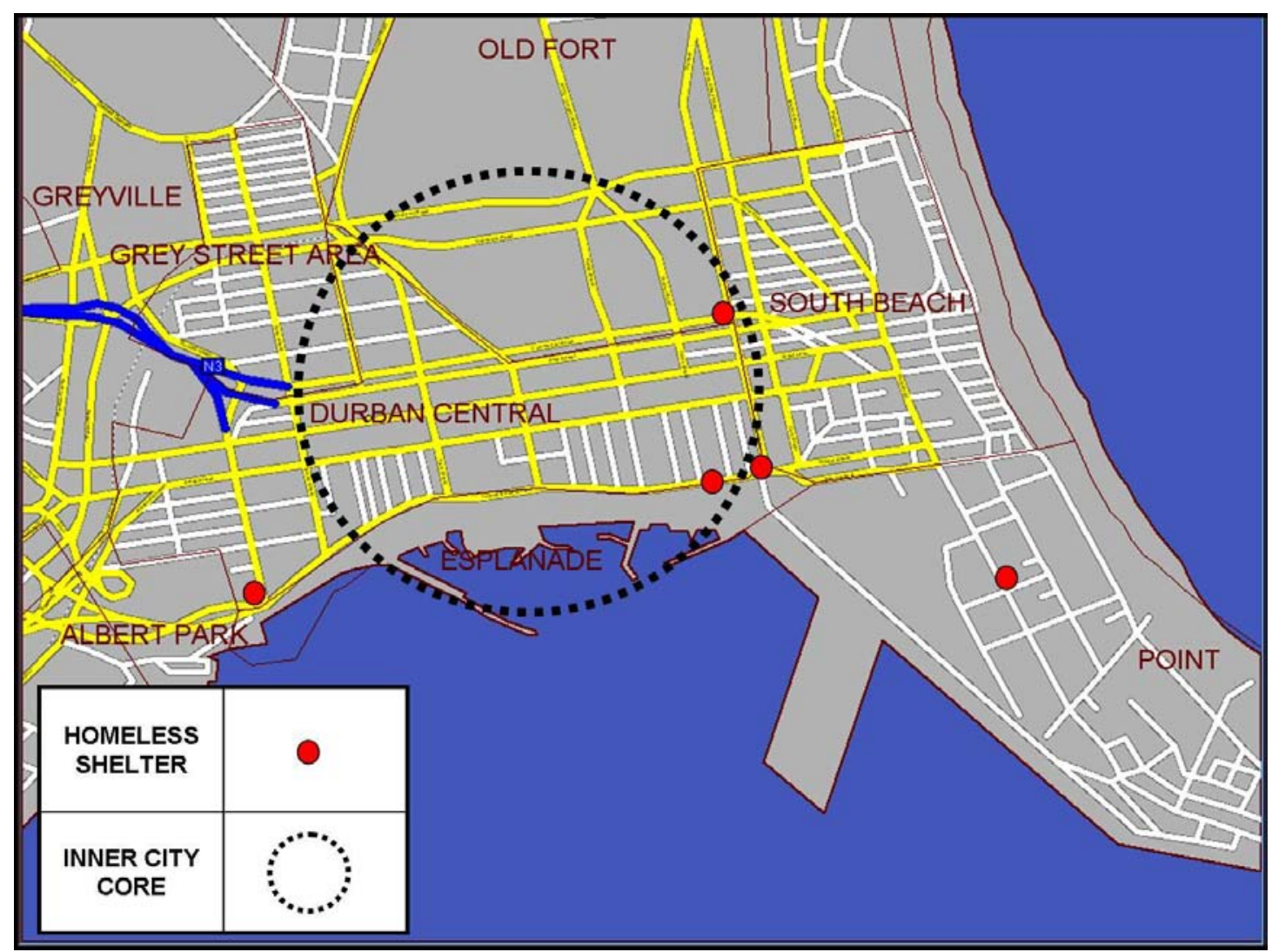

Map 3: Shelter locations around Johannesburg inner city

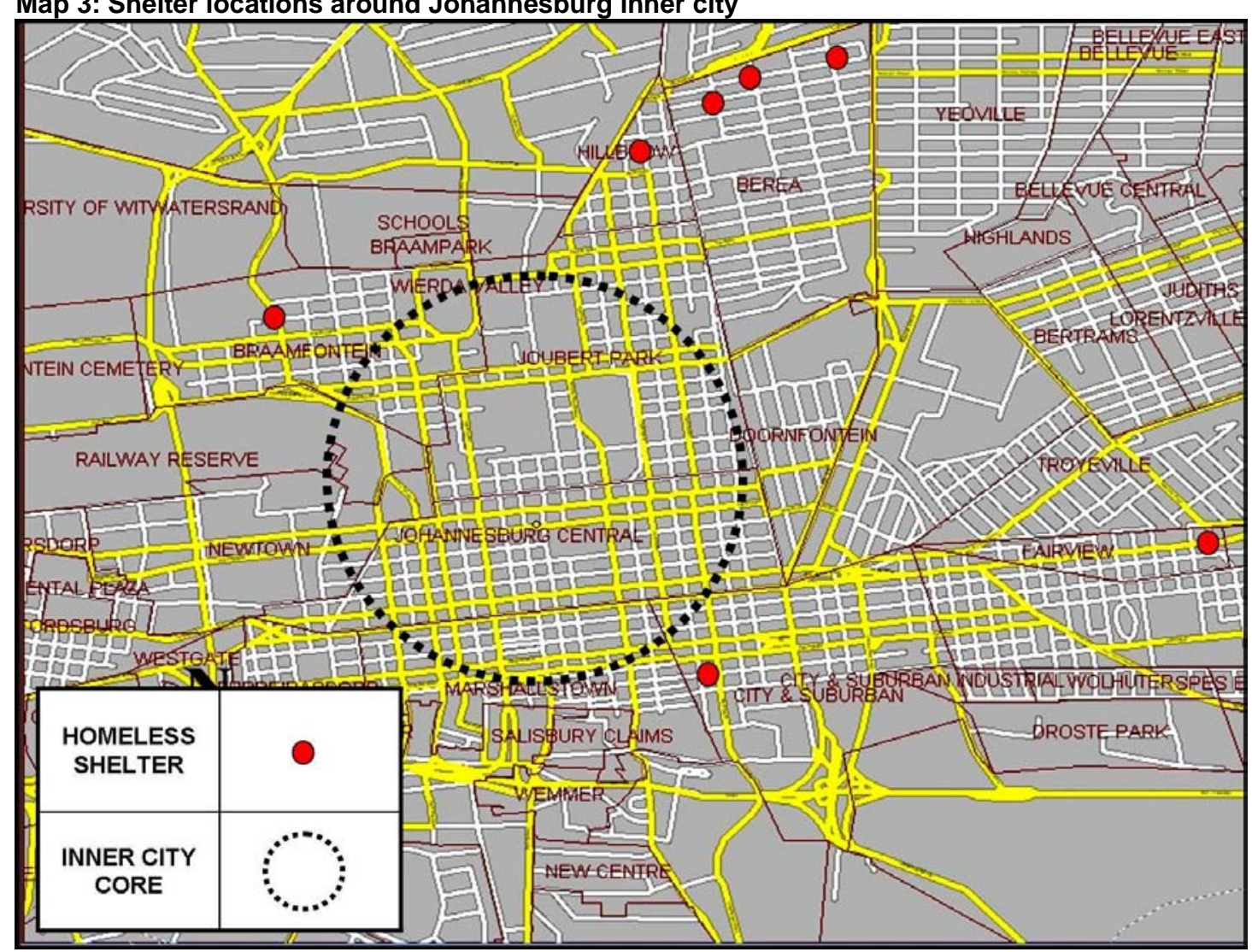


Map 4: Shelter locations around Pretoria inner city

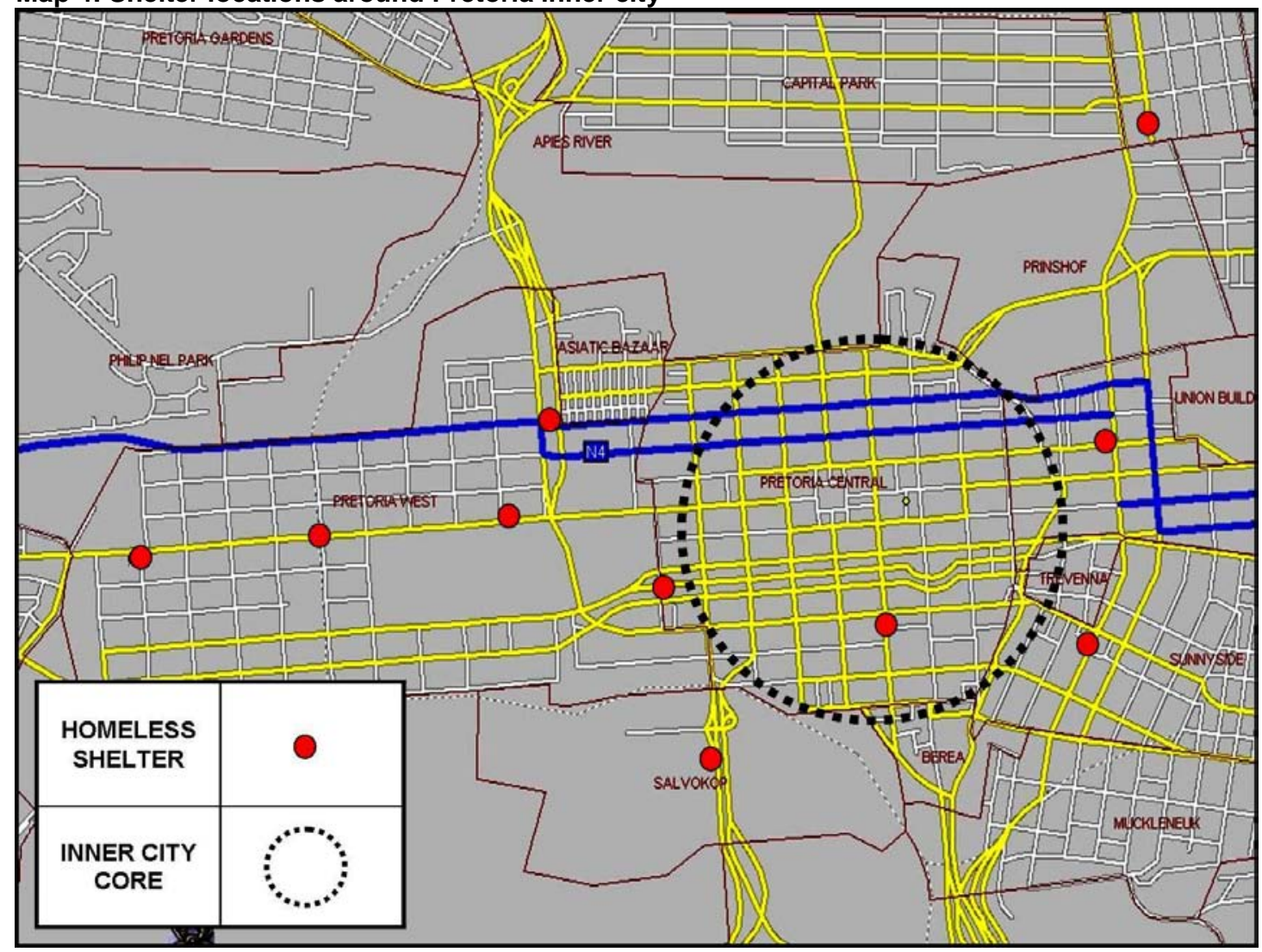

\subsection{Homeless people’s views}

This section of the study used data from the HSRC survey to determine what the homeless in central Johannesburg and Tshwane thought was the most important thing the municipality could have done for them. Table 4 shows that more than half of the homeless persons here (53.7\%) chose 'provide employment'. The second largest percentage (34\%) opted for housing. Very few opted for support (7.3\%). Those who chose housing were also asked what kind of housing would be most useful given their current circumstances and where such housing should be located.

Table 5 shows that the majority (62.8\%) opted for affordable self-owned housing, whereas only $18.9 \%$ opted for affordable rental housing and $18.2 \%$ for a place in a shelter for the homeless. Interestingly, a larger proportion of those who opted for a place in a shelter thought that shelters would be best located near town and other places of economic opportunities, whereas larger proportions of those who opted for affordable rental housing or self-owned housing thought that such housing would be best located in a local township or suburb respectively. The lower one moves down the housing typology from self-owned to rental housing to shelters for the homeless, the stronger the preference to be located near town and other places of economic opportunities. This relationship between housing and location preferences is statistically significant at the 95\% confidence level $\left(\chi^{2}(4, N=148)=48.92, p\right.$ $=.00$ ), and the relationship is also moderately strong (Cramér's $V=.407)$. Therefore, when homeless people think about their housing options, what type of housing it is and where it is located are both important considerations for them. 
Table 4: Responses to the question 'What is the most important thing the municipality can do for you?

\begin{tabular}{|c|c|c|c|c|c|c|}
\hline & \multicolumn{2}{|c|}{ Johannesburg } & \multicolumn{2}{|c|}{ Tshwane } & \multicolumn{2}{|c|}{ Total } \\
\hline & Number & $\%$ & Number & $\%$ & Number & $\%$ \\
\hline Provide employment & 84 & 55.3 & 164 & 52.9 & 248 & 53.7 \\
\hline Provide housing & 56 & 36.8 & 101 & 32.6 & 157 & 34.0 \\
\hline Provide support & 8 & 5.3 & 26 & 8.4 & 34 & 7.3 \\
\hline Other & 4 & 2.6 & 19 & 6.1 & 23 & 5.0 \\
\hline Total & 152 & 100.0 & 310 & 100.0 & 462 & 100.0 \\
\hline
\end{tabular}

Note: 'Provide support' includes emergency assistance, primary health care, skills training, pension or grants.

Table 5: Responses to the question 'What kind of housing would you prefer and where should it be located?'

\begin{tabular}{|c|c|c|c|c|c|c|c|c|}
\hline \multirow{3}{*}{$\begin{array}{l}\text { Preferred housing } \\
\text { type }\end{array}$} & \multicolumn{8}{|c|}{ Preferred locations } \\
\hline & \multicolumn{2}{|c|}{$\begin{array}{l}\text { Near town, factories, } \\
\text { markets, or other } \\
\text { homeless shelters }\end{array}$} & \multicolumn{2}{|c|}{ In a local suburb } & \multicolumn{2}{|c|}{ In a local township } & \multicolumn{2}{|c|}{ Total } \\
\hline & Number & $\%$ & Number & $\%$ & Number & $\%$ & Number & $\%$ \\
\hline $\begin{array}{l}\text { Place in a homeless } \\
\text { shelter }\end{array}$ & 25 & 47.2 & 0 & 0.0 & 2 & 2.5 & 27 & 18.2 \\
\hline $\begin{array}{l}\text { Affordable rental } \\
\text { housing }\end{array}$ & 10 & 18.9 & 3 & 21.4 & 15 & 18.5 & 28 & 18.9 \\
\hline $\begin{array}{l}\text { Affordable self- } \\
\text { owned housing }\end{array}$ & 18 & 34.0 & 11 & 78.6 & 64 & 79.0 & 93 & 62.8 \\
\hline Total & 53 & 100.0 & 14 & 100.0 & 81 & 100.0 & 148 & 100.0 \\
\hline
\end{tabular}

\section{Conclusion and recommendations}

Indications are that the numbers of homeless persons in the South African metropolitan municipalities are likely to increase in the foreseeable future and so the way municipalities respond will become increasingly important in alleviating their plight. This paper examined local metropolitan government responses to homelessness, looking in particular at the municipal departments primarily responsible for dealing with the problem. The study took a critical social science perspective by problematising homelessness and critically examining municipal responses so as to be in a position to recommend improvements.

The literature reviewed here highlights the importance of looking at the relationship between homelessness and urban space and the need for providing affordable housing when considering municipal responses. Yet this research found that three of the four metropolitan municipalities in the sample viewed homelessness primarily as a social dependency issue, and as a result their responses focused on coordinating civil society responses, putting in place a range of targeted interventions, and responding to public complaints. Although they were well prepared on a policy level, they were less prepared on the level of implementation, while officials thought that municipal responses were influenced by national and provincial governments more than any other factor. Homeless people echoed the findings in the literature by saying that the most important thing the municipality could do for them would be to provide employment and affordable housing in a location that would suit their needs.

Nkomo and Olufemi (2001) argue that homelessness is a multifaceted phenomenon requiring a holistic response that would include social interventions pertaining to health, education, skills, survival strategies, and so on. However, this study found that metropolitan municipalities might respond more effectively with spatial or physical interventions such as 
equitable urban planning and design, land use management that is more sensitive to the needs of the homeless, and affordable housing close to places of employment. No agency other than local government carries greater responsibility for such interventions. Wright forcefully argues the same:

To conceive of homelessness simply as a problem for the Department of Human Services or for charity ignores the role city officials, planners, and developers have in structuring city spaces that lead to the exclusion and repression of its poor. Few city officials understand homelessness as an issue of land use; most prefer the politically safe understanding of homelessness as a social welfare issue. It is not simply a question of building more housing, or even creating more jobs, although those are necessary, but it is a question of where these new housing units will be built and what type of jobs will be created... Shelters do not solve homelessness. Decent jobs, housing, and health care do. (1997:308)

This study recommends that municipalities should:

- View homelessness primarily as an issue of lack of employment and affordable housing and locate the responsibility with local economic development and housing departments.

- Consolidate existing homelessness policies, strategies and programmes and focus more on implementing and monitoring programmes, provided that such programmes include substantive spatial and physical interventions.

- Provide shelters for the homeless and affordable rental housing close to inner cities, industrial parks and other places of employment, with affordable self-owned housing close to townships and other residential areas. It is important that housing is provided in places where there are actual employment opportunities, not just in zones of transition and other marginal urban spaces that shelters tend to get pushed into to by market forces, poor urban planning and NIMBYism ('not-in-my-backyard'). Indeed, Social and Cooperative Housing are meant to provide housing near employment.

- Plan and design urban spaces and settlements to be more sensitive to the needs of vulnerable groups, including the homeless. This does not require a major overhaul of existing planning and design practices, only the political will and technical know-how to implement sustainable planning and design principles, such as mixed land uses facilitating greater social and economic opportunities, pedestrian and human-scale development, and 'crime prevention through environmental design'. Urban planning and design fields have much to offer in terms of such normative principles to alleviate the plight of the homeless.

\section{Acknowledgements}

This work forms part of the Human Sciences Research Council's 2005-2008 study of homelessness. Funding from the National Department of Social Development, the HSRC, the Gauteng Department of Social Development and the Swiss Agency for Development and Cooperation is gratefully acknowledged. 
The author would like to thank both reviewers for their comments, which helped make noticeable improvements to this article.

\section{References}

Aliber, M, 2002. Overview of the incidence of poverty in South Africa for the 10-Year Review. (HSRC) Human Sciences Research Council, Pretoria.

Aliber, M, Du Toit, J, Langa, Z, Msibi, M, Parthab, S, Roberts, B \& Thaba, F, 2004. Poverty on our doorstep: Understanding the situation of the individuals who spend the night in front of 134 Pretorius Street and the possible implications of erecting a fence to keep them out. Unpublished report. HSRC (Human Sciences Research Council), Pretoria.

America magazine (National Catholic Weekly magazine), 2003. Ever-rising hunger and homelessness. Editorial, 17 February.

www.americamagazine.org/content/article.cfm?article_id=2789 Accessed 10 November 2009.

Amster, R, 2003. Patterns of exclusion: Sanitizing space, criminalizing homelessness. Social Justice 30(1), 195.

Berman, EM \& West, JP, 1997. Municipal responses to homelessness: A national survey of 'preparedness'. Journal of Urban Affairs 19(3), 303-18.

Caplow, T, Bahr, HM \& Sternberg, D, 1968. Homelessness. In Sills, DL (Ed.), International Encyclopaedia of the Social Sciences, Vol. 6. Free Press, New York.

Da Costa Nunez, R \& Caruso, LM, 2003. Are shelters the answer to family homelessness? USA Today, January.

Daly, G, 1996. Homeless: Policies, Strategies, and Lives on the Street. Routledge, London.

Dear, ML \& Wolch, JR, 1987. Landscapes of Despair: From Deinstitutionalization to Homelessness. Princeton University Press, Princeton, NJ.

Elliott, M \& Krivo, LJ, 1991. Structural determinants of homelessness in the United States. Social Problems 38(1), 113-31.

Furnell, BA, 1996. User friendly bibliography on street people. Institute of Criminology, University of Cape Town.

Glasser, I, 1994. Homelessness in Global Perspective. GK Hall, New York.

Hoch, C, 2000. Sheltering the homeless in the US: Social improvement and the continuum of care. Housing Studies 15(6), 865-76.

Honig, M \& Filer, RK, 1993. Causes of intercity variation in homelessness. The American Economic Review 83(1), 248-55.

IRIN News, 2007. Poor squatters make way for 2010 World Cup. 13 April. www.irinnews.org/Report.aspx?ReportId=71599 Accessed 12 November 2009.

Lee, BA \& Prince-Spratlen, T, 2004. The geography of homelessness in American communities: Concentration or dispersion? City \& Community 3(1), 3-27.

Lee, BA, Prince-Spratlen, T \& Kanan, JW, 2003. Determinants of homelessness in metropolitan areas. Journal of Urban Affairs 25(3), 335-55.

Lofland, LH, 1998. The Public Realm: Exploring the City's Quintessential Social Territory. Aldine, New York.

Mitchell, D, 2001. Postmodern geographical praxis? The postmodern impulse and the war against the homeless in the 'post-justice' city. In Minca, C (Ed.), Postmodern Geography: Theory and Praxis. Blackwell, Oxford.

Murray, MJ, 2004. The Evolving Spatial Form of Cities in a Globalising World Economy: Johannesburg and Sao Paulo. HSRC (Human Sciences Research Council) Press, Cape Town. 
Nkomo, M \& Olufemi, O, 2001. Educating street and homeless children in South Africa: Challenges of policy implementation. Special Issue, International Journal of Educational Policy, Research and Practice 2(4), 337-56.

Oakley, D, 2002. Housing homeless people: Local mobilization of federal resources to fight NIMBYism. Journal of Urban Affairs 24(1), 97-116.

Poulsen, L, 2000. The transitional housing programme for the inner city homeless community of Johannesburg. Paper presented at the Urban Futures 2000 International Conference, Johannesburg, 10-14 July.

Powell, A, 2006. Groups slam 'bylaw out of the Dark Ages'. Cape Times, 20 June, p.5.

Rahimian, A, Wolch, JR \& Koegel, P, 1992. A model of homeless migration: Homeless men in Skid Row, Los Angeles. Environment \& Planning A, 24(9), 317-36.

Robins, S, 2002. At the limits of spatial governmentality: A message from the tip of Africa. Third World Quarterly 23(4), 665-89.

SACN (South African Cities Network), 2004. State of our cities report. South African Cities Network, Braamfontein.

SACN (South African Cities Network), 2006. State of our cities report. Braamfontein: South African Cities Network South African Cities Network, Braamfontein.

Snow, DA \& Mulcahy, M, 2001. Space, politics, and the survival strategies of the homeless. The American Behavioral Scientist 45(1), 149-72.

Takahashi, LM, 1997. The socio-spatial stigmatization of homelessness and HIV/AIDS: Towards an explanation of the NIMBY syndrome. Social Science \& Medicine 45(6), 903-14.

Wolch, JR, 1980. Residential location of the service-dependent poor. Annals of the Association of American Geographers 70(3), 330-42.

Wolch, JR, 1997. Shifting margins of housing status in Los Angeles. Social Science Research 26(3), 309-31.

Wolch, JR, 1998. America's new urban policy: Welfare reform and the fate of American cities. Journal of the American Planning Association 64(1), 8-12.

Wolch, JR \& Dear, MJ, 1993. Malign Neglect: Homelessness in an American City. JosseyBass, San Francisco.

Wolch, JR \& Sommer, H, 1997. Los Angeles in an era of welfare reform: Implications for poor people and community well-being. Southern California Inter-University Consortium on Homelessness and Poverty, California.

Wright, T, 1997. Out of Place: Homeless Mobilizations, Subcities, and Contested Landscapes. State University of New York Press, Albany.

\section{Annexure: Municipal documents reviewed}

Cape Metropolitan Council, 2000. Street field workers project: Audit \& report on the reality of street people in the Cape metropolitan area.

City Council of Pretoria, 1999. Department of Community Upliftment Policy on Homelessness.

City of Cape Town, (date unknown). Street people policy document.

City of Cape Town, 2004. City of Cape Town integrated multi-sectoral street children initiative.

City of Tshwane Metropolitan Municipality, 2004. Homelessness in Tshwane: Strategic plan.

City of Tshwane Metropolitan Municipality, 2004. Policy for dealing with homeless people in the City of Tshwane.

City of Tshwane Metropolitan Municipality, 2004. Strategy on homelessness. 
Ethekwini Municipality, 2004. Development of an action plan to address the plight of street children.

Greater Johannesburg Transitional Metropolitan Council, 1996. Policy on inner city transitional housing. 